\title{
Re-use Intention of Online Learning Platform
}

\author{
${ }^{1}$ Faculty of Economics and Business, Universitas Bengkulu, Bengkulu, Indonesia \\ ${ }^{2}$ Faculty of Economics and Business, Universitas Bengkulu, Bengkulu, Indonesia \\ ${ }^{3}$ Faculty of Economics and Business, Universitas Bengkulu, Bengkulu, Indonesia \\ ${ }^{4}$ Faculty of Economics and Business, Universitas Bengkulu, Bengkulu, Indonesia \\ *Corresponding author. Email: akramharmoniw@gmail.com
}

Akram Harmoni Wiardi ${ }^{1, *}$, Trisna Murni ${ }^{2}$, Rina Suthia Hayu ${ }^{3}$, Effed Darta Hadi ${ }^{4}$

\begin{abstract}
The Technology Acceptance Model (TAM) is a model used to predict user acceptance of information systems based on perceived usefulness and perceived ease of use. If the user sees the benefits and ease of using the information system, it will cause the user's actions to accept the use of the information system. The objectives of this research is to examine the effect of quality of information system and perceived usefulness on the intention to reuse online learning platform. This research analyze the measurement of perceptions of the quality of the IT system used by respondents in the scope of online learning. We operate a survey method, the respondents in this research were students and lecturers that use online learning platforms. Respondents, most of whom are students in Sumatra, are interested or have the intention of reusing online learning applications if there is a good information quality factor and more benefits from online applications. The perceived usefulness construct plays a full role as a mediating variable of the relationship between information quality and intention to reuse online learning applications.
\end{abstract}

Keywords: usefulness, online, intention, platform, technology, acceptance.

\section{INTRODUCTION}

The need for online learning during the COVID-19 pandemic is massively needed to kept the learning process are sustainable. Along with the development of technology and to assist the teaching and learning process, an e-learning application system is needed. ELearning is a learning method that utilizes computer technology, computer networks and/or the Internet. ELearning allows students to learn via computers in their respective places without having to physically go to lectures in class like conventional lectures.

According to [1], multimedia is a combination of two or more media that are integrated in the form of information or learning programs. Learning using web-based interactive media and electronic learning (e-learning) is a multimedia learning. Two-way communication and interaction will take place more effectively between teachers and students. The teacher delivers learning materials and students respond to the learning materials they receive. According to Gagne [2], the teacher not only acts as a transmitter of material, but also receives feedback from students and provides reinforcement (re-inforcement) on the learning outcomes they have taken. Some examples of network-based interactive multimedia learning facilities (websites) that can be used include Cisco Webex, Zenius, Ruang Guru, TuWeb, and other online-based interactive media.

TAM theorizes that the effects of external variables (eg, system characteristics, process development, training) on intention to use an application are mediated by perceived usefulness and perceived ease of use. According to TAM theory, perceived usefulness is also influenced by perceived ease of use because, all in all, the easier the system is to use the more useful it is [3]. Significant progress has been made over the last decade in explaining and predicting user acceptance of information technology at work. In particular, substantial theoretical and empirical support has accumulated in favor of the Technology Acceptance Model [4].

However, most of the research on innovation so far has only focused on the process of sharing knowledge to obtain new knowledge resources that aim to improve the company's innovation capability [5], 
because basically innovation activity is how to implement knowledge, ideas or new activities into the firm. [6] if companies want to be innovative, companies must interact and exchange knowledge and ideas with other parties in their environment.

This study was compiled based on the Theory of Reasoned Action (TRA) to measure individual attitudes and behavior towards satisfaction with the use of information systems. TRA, which was developed by Fishbein and Ajzen (1975), is a theory related to the attitudes and behavior of individuals in carrying out activities [7].

TRA was adopted by the Technology Acceptance Model (TAM), which is a model introduced by [4] which describes the behavioral aspects of information system users. TAM is a model used to predict user acceptance of information systems based on perceived usefulness and perceived ease of use. If the user sees the benefits and ease of using the information system, it will trigger the user's actions to accept the use of the information system. This research was conducted to examine the relationship between the quality of the information technology system and the perceived usefulness on the intention to reuse information technology systems.

The concept of TAM is expressed based on the theory of rational behavior which assumes that humans have a rational nature, and human social behavior is not influenced by coercion or unconsciousness. Based on this theory, it can be seen that rational human behavior is a decision made by an individual in a conscious and not forced state. However, [3] revealed a more complex and effective theory called Technology Adoption and Utilization Integration Theory which consists of four core concepts such as performance expectations, hard-work expectations, social influence, and contributory factors, as well as four accompanying variables, namely gender, age, experience and voluntary. This research does not measure the concept of consumer expectations regarding the performance of technology-based services and social factors as did [3], however, focuses more on testing the relationship between information technology quality, perceived usefulness, and intention to reuse online learning applications.

\section{THEORETICAL FRAMEWORK}

\subsection{Quality of Information Technology}

The quality of information systems is defined by [8] as perceived ease of use which is the level of how much computer technology is felt to be relatively easy to understand and use. The quality of information systems shows that if information system users feel that using the system is easy, users do not require much effort to use it, so they will have more time to do other things that are likely to improve their overall performance. The results obtained by [9] - [12] show that the quality of information systems has a positive effect on user satisfaction.

To analyze the quality of the technology used by the company, it can be observed based on 2 aspects, namely the level of innovation carried out and the scope of innovation carried out [13]. The level of innovation carried out is divided into radical innovation and incremental innovation [14]. Meanwhile, based on the scope of innovation carried out, it is divided into technical innovation and administrative innovation [15]. Technical innovation is seen from the product, service, marketing, and technology used to produce the product or service which is the main activity of the company. Administrative innovation is seen from the innovations made to the organizational structure and administrative processes of the company.

\subsection{Perceived Usefulness}

[8] defines usefulness as a level where a person believes that the use of a particular subject will be able to improve the person's work performance. Perceived usefulness is defined as the extent to which a person believes that using a technology will improve his or her job performance. Perceived usefulness is a belief about the decision-making process, if someone believes that the information system is useful, then he will use it. On the other hand, if someone believes that the information system is less useful then he will not use it. So from this definition it can be interpreted that the benefits of using computers can improve performance and work performance of people who use them.

[16] examined the relationship between perceived usefulness and user satisfaction by using three models of information system success. The three models are the DeLone and McLean information system success model, the Seddon Model, and the Seddon Model which were modified by adding the relationship between perceived usefulness and system use. The results of the research as a whole show that perceived usefulness has an effect on user satisfaction.

[17] empirically tests the level of technology acceptance by consumers which specifically examines the concept of Value-based Adoption Model (VAM) 
in the hospitality industry with the moderating variable of consumer demographic information. Self-service technology that uses artificial intelligence technology can be applied to robotic technology services in the hotel industry. Trends in technology use are based on consumer needs, level of service quality, and modification of excellent service in the hospitality industry.

The concept used in this study is the concept of value-based adoption of technology (Value-based Adoption Model) which consists of perceived usefulness, quality of information technology, and intention to use technology. In contrast to the research of [3] in this study more reveal the psychological perceptions of behavioral inention.

\subsection{Intention to Re-use Online Learning Applications}

Repurchase intention has been conceptualized as the probability that a consumer plans, or needs, to purchase a particular good or service in the future [18]. Return or continuation intention is the probability that a customer who has purchased and used a good or service plans to continue buying and using it.

[9] found that system quality can affect user satisfaction. DeLone and McLean's success model suggests that system quality measures technical success, information quality measures semantic success, and system use, user satisfaction, individual impact and organizational impact measure success effectiveness. [9] assume that system quality and information quality, individually and together, affect user satisfaction and reuse intention.

This research focuses more on measuring consumer intention to reuse the learning application in terms of acceptance of new technology so that it is different from the research conducted by [3],[19]. In this study, there are several differences with [20] which revealed that the use of robotic services in the hotel industry in Japan is constrained by the ability of robotic automation technology which is not able to reduce the workload of employees and does not reduce operational costs. [21] revealed that to be able to work optimally, robotic automation systems must be able to determine the relationship between hotel management needs, robotic systems, and consumer needs.

[17] revealed that behavioral intentions using robotic applications in the hospitality industry can be influenced by several factors, namely perceptions of positive attitudes, perceptions of usefulness, perceived value, sentimental value, behavioral control, and ease of use of technology-based services. [22] conducted an empirical test of the technology acceptance model (TAM) following the research method conducted by [4]. The results of his research reveal that perceived usefulness has a significant effect on intention to use the internet. Perception of convenience does not have a direct effect on intention to use the internet, specifically it can affect use intention if it passes through the perception of usefulness.

E-Learning is a learning method that utilizes computer technology, computer networks and/or the Internet. E-Learning allows students to learn via computers in their respective places without having to physically go to lectures in class like conventional lectures. With the existence of e-learning is expected to help students to better understand the learning material provided by the lecturer. Based on the literature review and previous research, we formulated three hypotheses and the research model is presented in Figure 1.

H1: the quality of the information system has a significant effect on the perceived usefulness of online learning applications.

$\mathrm{H} 2$ : perceived usefulness has a significant effect on the intention to reuse online learning applications.

H3: the quality of the information system has a significant effect on the intention to reuse online applications.

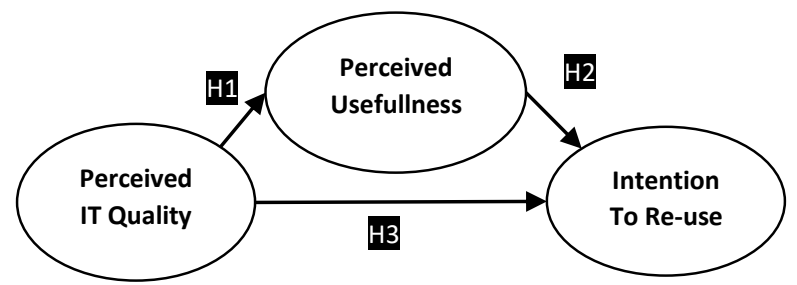

Figure 1. Research Model

Source: adapted from [10], [12], [13]

\section{RESEARCH METHOD}

A survey method was operated by using online questionnaires to obtain primary data directly. Online survey was conducted via email and online form survey. We operate purposive sampling technique, the respondents are the students and lecturers that already use interactive multimedia-based online learning applications such as Zoom meeting, Google Teams, isco Webex, zenius, Ruang Guru, TuWeb, and other online-based interactive media that enable to use in Sumatera. 


\subsection{Questionnaire Design and Research Measurement Tools}

1. The perceived usefullness was measured using a 5point Likert scale with five answer options. This measurement item was adopted from [23].

2. The information system quality was measured using a 5-point Likert scale with five answer options, This measurement item was adopted from [9].

3. The variable of re-use intention is the perception of individuals which consists of four cognitive; intention to recommend, intention to use the same internet provider, hope in the future, and intention to use the next service. This measurement item was adopted from [4], [23], and [24].

\subsection{Validity and Reliability of Measurement}

Data collection in this study was carried out by distributing online questionnaires to respondents. The data collection process was carried out for 2 weeks to 200 respondents and resulted in a total of 194 questionnaires that were eligible to be processed. The reliability test was shown by the value of Cronbach's Alpha. Reliability test was operated by using SPSS and produced a value above 0.8 on all construct.

Confirmatory factor analysis was performed to execute validity test for each indicator item in this study. In particular, the results of the validity of each indicator on the variables of information system quality, perceived usefullness, and intention to reuse online learning applications.

In the re-use intention variable, there is one indicator that has a loading factor value of less than 0.5 , namely the npu4 indicator. The indicator with code npu 4 which states "I intend to use online learning media in the future" has a loading factor value of less than 0.5 so that the item must be dropped and not included in the next process. Respondents perceive that in carrying out learning activities they do not only use online learning media. It seems that respondents in general do not want to continuously use online learning methods.

It is believed by researchers that respondents in the Sumatran area, especially in Bengkulu Province, there are still areas that are not covered by a good internet signal, so this hampers the online learning process. This is confirmed in the respondent's statement regarding the perceived usefulness of the effectiveness of online learning which states 'Online learning is effective' with the code u5 which has a loading factor value below 0.4 .

\subsection{Hypotheses Test Technique}

The analysis of the measurement model in this research was carried out using Confirmatory Factor Analysis (CFA), the researcher will only examine one research model and use structural equation modeling (SEM) to assess how well the model fits the empirical data [19]. In order to test the hypotheses we operate the regression analysis based on structural equation modelling, bywich looking at the critical ratio value generated from the calculation of loading of each relationship between constructs contained in the research model and looking at the estimated value of standardized regression weights.

\section{RESULT AND DISCUSSION}

\subsection{The Results of Structural Equation Modelling (SEM)}

\subsubsection{Result of Measurement Model Test}

AMOS 20 software program was operated to analyze Structural Equation Modeling based on confirmatory factor analysis. Figure 2 is the result of measurement model test based on SEM.

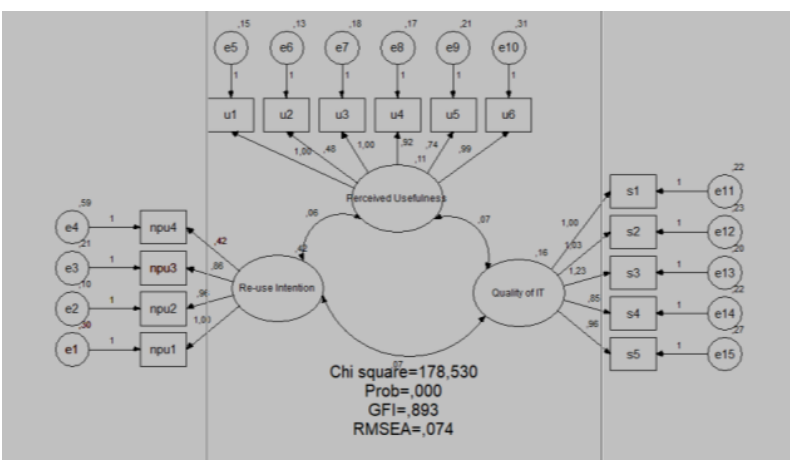

Figure 2. Result of Measurement Model

Based on Table 1, the chi-square $\left(\mathrm{X}^{2}\right)$ value is 178,530 and the chi-square probability is 0.000 , below 0.005 . This value indicates that the measurement model is quite good. According to [24], the results of the chi-square test $\left(\mathrm{X}^{2}\right)$ are not too problematic, researchers must always complete the test with another goodness of fit index, as important as the others, the chi-square value $\left(\mathrm{X}^{2}\right)$ and degree of freedom (df) should always be reporthaed. While the value of the normed chi-square $\left(\mathrm{X}^{2} / \mathrm{df}\right)$ is known to be 2.052 which indicates that this measurement model has a good fit based on the empirical data and appropriate based the value of the goodness of fit index, which is less than 
3.00. The GFI value of the measurement model, the CFI Index, and the RMSEA shows a good fit between the measurement model and the empirical data.

Table 1. Goodness of Fit Index of Measurement Model

\begin{tabular}{||l|c|}
\hline \multicolumn{1}{|c|}{ Index Goodness offit } & Score \\
\hline Chi-square $\left(\mathrm{X}^{2}\right)$ & 178,530 \\
\hline $\begin{array}{l}\text { Probabilitas Scaled Chi-square } \\
\text { (p-value })\end{array}$ & 0,000 \\
\hline Degree of freedom $(d f)$ & 87 \\
\hline Normed Chi-square $(X 2 / d f)$ & 2,052 \\
\hline Goodness of Fit Index $(G F I)$ & 0,893 \\
\hline Comparative Fit Index $($ CFI $)$ & 0,885 \\
\hline $\begin{array}{l}\text { Root Mean Square Error of } \\
\text { Approximation }(\text { RMSEA })\end{array}$ & 0,074 \\
\hline
\end{tabular}

Source: processed data, 2020.

\subsubsection{Result of Structural Model Test}

After analyzing the measurement model, the next step is to analyze the structural model. Figure 3 is the result of structural model measurement based on SEM.

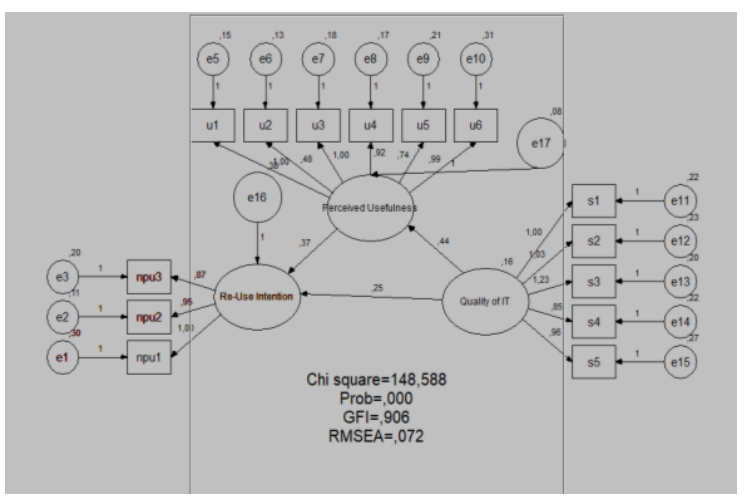

Figure 3. Result of Structural Model

Table 2. Goodness of Fit Index Structural Model

\begin{tabular}{||l|c||}
\hline \multicolumn{1}{|c|}{ Goodness of fit Index } & Score \\
\hline Chi-square $\left(\mathrm{X}^{2}\right)$ & 148,588 \\
\hline $\begin{array}{l}\text { Probabilitas Scaled Chi-square }(p- \\
\text { value })\end{array}$ & 0,000 \\
\hline Degree of freedom $(d f)$ & 74 \\
\hline Normed Chi-square $(X 2 / d f)$ & 2,008 \\
\hline $\begin{array}{l}\text { Goodness of Fit Index }(G F I) \\
\text { Comparative Fit Index }(C F I)\end{array}$ & 0,906 \\
\hline $\begin{array}{l}\text { Root Mean Square Error of } \\
\text { Approximation }(\text { RMSEA) }\end{array}$ & 0,902 \\
\hline \hline
\end{tabular}

Source: processed data, 2020.
Based on Table 2, the chi-square $\left(\mathrm{X}^{2}\right)$ value is 148,588 with the structural model degree of freedom value in this study of 74 so that the normed chi-square $\left(\mathrm{X}^{2} / \mathrm{df}\right)$ value is 2.008 . The value of the Normed Chisquare $\left(\mathrm{X}^{2} / \mathrm{df}\right)$ is greater than 3.00 so that the structural model in this study has a good match with the empirical data. The RMSEA value of 0.072 is in the range of values of 0.03 and 0.08 , this indicates that the structural model has a good fit on the empirical data. The comparison of goodness of fit values between measurement model and structural model shows that structural test are preferable than the value of the GOF the measurement model, this indicates that this structural model has goodness of modelling validity and goodness of fit.

\subsubsection{Hypotheses Test}

We refer to the critical ratio value which is \pm 1.96 at a significance level of 0.05 . If the critical ratio value is greater than \pm 1.96 then the causal relationship between the two constructs is significant. The existence of a positive or negative sign on the critical ratio value indicates a directly or inversely proportional relationship between the constructs tested in the study.

Based on Table 3, the value of regression estimation is 0.443 by a critical ratio value of 4.725 and $p$ value of $0.000(p<0.05)$. The results of first hypotheses testing ( $\mathrm{H} 1)$ shows positive and significant relationship, it indicates that the respondents' perceptions of the quality of information systems has a significant relationship on perceived usefulness of online learning applications. This statistical result supported the first hypotheses, perceived usefulness can be influenced by the reliability of the quality of the information system, respondents who feel the superior quality of information system tend to elevate the benefits of using online learning applications.

Based on Table 3 , the results of statistical test on the second hypotheses test (H2) shows the estimated regression value is 0.367 by a critical ratio value of 1.672 and $p$ value of $0.048(p<0.05)$. The result indicates that the relationship between perceived usefulness and the intention to reuse online learning applications has a positive and significant relationship between constructs. The respondents' perceptions of perceived usefulness have a positive relationship to the intention to reuse online learning applications. If respondents perceive that perceived usefulness is important, they will have a strong interest in using online learning applications. The test results can explain that hypothesis 2 (H2) which states that perceived usefulness has a significant effect on the 
Table 3. Significant and Estimation Value Relationship Between Construct

\begin{tabular}{|lrl|ccccl|}
\hline \multicolumn{2}{|c|}{$\begin{array}{c}\text { Relationship } \\
\text { Between construct }\end{array}$} & Estimate & S.E. & C.R. & $p$ & Info \\
\hline Usefulness & $<-$ & Quality of IT & $\mathbf{, 4 4 3}$ & $\mathbf{, 0 9 4}$ & $\mathbf{4 , 7 2 5}$ & $* * *$ & Significant \\
Intention to Reuse & $<-$ & Usefulness & $\mathbf{, 3 6 7}$ & $\mathbf{, 2 2 0}$ & $\mathbf{1 , 6 7 2}$ & $\mathbf{, 0 4 8}$ & Significant \\
Intention to Reuse & $<-$ & Quality of IT &, 254 &, 180 & 1,412 &, 158 & Not Significant \\
\hline
\end{tabular}

Source: processed data, 2020

intention to reuse online learning applications are supported.

The results of the third hypotheses testing (H3), as presented in Table 3, postulate that the perception of quality of information system has insignificant effect on the intention to reuse online applications. The statistical test shows a regression estimation value of 0.254 by critical ratio value of 1.412 and $p$ value of 0.158 ( $p>0.000)$. The results of the hypothesis test 3 show an insignificant relationship, so hypothesis 3 (H3) which states that the perception of the quality of the information system has a positive effect on the intention to reuse online applications is not supported in this reseacrh. The quality of the information system cannot directly affect the intention to reuse online applications.

The results of this research reveal that the construct of information system quality cannot effect the intention to reuse directly, but it is mediated by the construct of perceived usefulness, this is indicated by the results of statistical analysis on hypotheses testing. The role of perceived usefulness as a mediator of the relationship between the quality of information systems and the intention to reuse online learning applications is visible in this research. Good quality information must be accompanied by a good perceived usefulness of online learning applications to perform elevation of intention to reuse.

\section{CONCLUSSION}

The purpose of this research is to examine the relationship between information system quality, perceived usefulness, and intention to reuse online learning applications. The results can be concluded that:

1. The quality of the information technology has a positive and significant effect on perceived usefulness.

2. The perceived usefulness construct has a positive and significant effect on the intention to reuse online learning applications.
3. The quality of information technology has no significant effect on the intention to reuse online learning applications.

The findings in this study reveal that respondents are interested or have the intention of reusing online learning applications if there are factors of good information quality and more benefits from online applications. the perceived usefulness construct plays a full role as a mediating variable of the relationship between information quality and intention to reuse online learning applications.

\section{AUTHORS' CONTRIBUTIONS}

Akram Harmoni Wiardi ${ }^{1}$ devised the project, the main conceptual ideas and proof outline. Akram Harmoni Wiardi ${ }^{1}$ worked out the technical details and performed the statistical analysis for this research. Trisna Murni $^{2}$ verified the statistical result and interpreting statistical result, correlating the hypotheses statement. Akram Harmoni Wiardi ${ }^{1}$ and Trisna Murni ${ }^{2}$ proposed the survey method and wrote the manuscript. Rina Suthia $\mathrm{Hayu}^{3}$ and Effed Darta Hadi $^{4}$ operate the application of survey, data validation, and proof reading.

\section{ACKNOWLEDGMENTS}

We would like to express our gratitude to all respondents who contributed to this research, as well as to the Department of Management, Faculty of Economics and Business Universitas Bengkulu, which funded this research through a research grant program.

\section{REFERENCES}

[1] Heinich, Molenda, Russel, Intructional Media and New Technology of Instruction. Englewood Cliff, N.J.: Prentice-Hall, 1996

[2] R. Gagne, "Mastery Learning and Instructional Design", Performance Improvement Quarterly, vol. 1,pp. 7-18, 1988, doi: 10.1111/j.1937-8327.1988.tb00003.x 
[3] V. Venkatesh, M.G. Morris, G.B. Davis, and F.D. Davis, "User acceptance of Information Technology: Toward a Unified View," MIS Quarterly, pp. 425-478, 2003.

[4] F.D. Davis, "Perceived Usefulness, Perceived Ease of Use, and User Acceptance of Information Technology". MIS Quarterly. September, pp.319- 340, 1989.

[5] H.F. Lin, "The Role of Online and Offline Features in Sustaining Virtual Communities: an Empirical Study," Internet Research, vol. 17, no. 2, pp. 119-138, 2007.

[6] I. Miles, "Knowledge Intensive Business Services: Prospects and Policies," Foresight, vol. 7, no. 6, pp. 39-63, 2005

[7] I. Ajzen, "The Theory of Planned Behavior," Organizational Behavior and Human Decision Processes, vol. 50, pp. 179-211, 1991.

[8] F.D. Davis, R.P. Bagozzi, and P.R. Warshaw, "User Acceptance Of Computer Technology: a Comparison Two Theoretical Models," Management Science. August. pp. 982-1003, 1989.

[9] W.H. DeLone and E.R. Mclean, "Information System Success: The Quest for the Dependent Variable," Information System Research, March, pp. 60-95, 1992.

[10] V. McKiney, K. Yoon, and F. Zahedi, "The Measurement of Web-Customer Satisfaction: An Expectation and Disconfirmation Approach," Information System Research, vol. 133, pp. 296-315, 2002.

[11] T. McGill, V. Hobbs, and J. Klobas, "UserDeveloped Applications and Information Systems Success: a Test of DeLone and McLean'sModel," Information resource Management Journal, vol. 16, no. 1, pp. 24, 2003.

[12] J. Livari, “An Empirical Test of the DeLone and McLean Model ofInformation System Success," Database for Advances in Information Systems. Spring vol. 36, no. 2, pp. 8, 2005.

[13] R. J. Lin, R.H. Chen, and K.K.S Chiu, "Customer Relationship Management and Innovation Capability: An Empirical Study," Industrial Management \& Data Systems, vol. 110(1),pp. 111-133, 2010
[14] H. Salavou and S. Lioukas, "Radical Product Innovations in SMEs: The Dominance of Entrepreneurial Orientation," Creativity and Innovation Management, vol.12, pp.94-108, 2003

[15] A. Afuah, Innovation Management: Strategies, Implementation and Profits. Oxford: Oxford University Press, 2003

[16] A. Rai, S.S. Lang, and R.B. Welker, "Assessing the Validity of IS Success Models: An Empirical Test and Theoretical Analysis," Information Systems Research, vol. 13, no. 1, pp.50-69, 2002.

[17] L. Zhong, X. Zhang, J. Rong, H.K. Chan, J. Xiao, and H. Kong, "Construction and Empirical Research on Acceptance Model of Service Robots Applied in Hotel Industry," Industrial Management \& Data Systems, 2020.

[18] 18 L.G. Schiffman and L.L. Kanuk, Consumer Behavior, $8^{\text {th }}$ international ed. Upper Saddle River, NJ: Prentice Hall, 2004.

[19] T. Pikkarainen, K. Pikkarainen, H. Karjaluoto, and S. Pahnila, "Consumer Acceptance of Online Banking: An Extension of The Technology," Internet Research, vol. 14, no. 3, pp. 224-235, 2004.

[20] E. Hertzfeld, Japan's Henna Hotel Fires Half Its Robot Workforce [internet], Hotel Management, 2019, available at: https://www.hotelmanagement.net/tech/japans -henn-na-hotel-fires-half-its-robot-workforce.

[21] J. Murphy, U. Gretzel, and J. Pesonen, "Marketing Robot Services in Hospitality and Tourism: The Role of Anthropomorphism", Journal of Travel and Tourism Marketing, vol. 36, no. 7, pp. 784-795, 2019.

[22] 22 B. Szajna, "Empirical Evaluation of the Revised Technology Acceptance Model," Management Science vol. 42, no. 1, pp. 85-92, 1996, doi: 10.1287/mnsc.42.1.85.

[23] W. Abdillah, "The Effects Dispositional And Situational Cognitive Factors On The Intention To Use Internet:An Empirical Study Of The Acceptance Of Information Technology At Universitas Bengkulu," Journal of Indonesian Economy and Business, Vol. 24, No. 2, pp. 177 - 204, 2009. 
[24] J.F. Hair, W.C. Black, B.J Babin, R.E. Anderson, and L. Ronald. Multivariate Data Analysis: A Global Perpective (7th Edition). New Jersey: Pearson, 2010. 